\title{
RADIOCARBON RESULTS FROM THE IRON IIA SITE OF ATAR HAROA IN THE NEGEV HIGHLANDS AND THEIR ARCHAEOLOGICAL AND HISTORICAL IMPLICATIONS
}

\author{
Elisabetta Boaretto ${ }^{1}$ Israel Finkelstein ${ }^{2}$ Ruth Shahack-Gross ${ }^{3}$
}

\begin{abstract}
In this article, we present a set of radiocarbon measurements from Atar Haroa, a site that belongs to the early Iron IIA Negev Highlands settlement system in southern Israel. The results place activity at the site in the 9th century BCE, with a possibility that it was founded in the 10th century BCE, probably in the second half. The Atar Haroa measurements seem to indicate that the early Iron IIA phase in the ceramic typology of Israel lasted until the mid-9th century BCE-somewhat later than previously suggested. These new data shed light on several issues related to the history of southern Israel in the late 10th and 9th centuries BCE.
\end{abstract}

\section{INTRODUCTION}

The settlement history of the Negev Highlands is characterized by sharp oscillations. Several periods - the Early Bronze II, Intermediate Bronze, early Iron IIA, and Byzantine/Early Islamic - feature relatively strong human activity, with remains from hundreds of sites spread across the region. Other periods, such as the Middle and Late Bronze Ages, most of the Iron Age and Medieval times, left no material remains behind. Scholars have debated the reasons for these oscillations. Some related these oscillations to climatic changes (e.g. Rosen 1987), and argued that periods with no remains reflect a very low profile of human activity if not a population void. Others (e.g. Finkelstein 1995) explained the oscillations in terms of sociopolitical and economic changes within the local desert population, that is, as shifts along the nomadic-sedentary continuum.

The settlement system of the Iron Age IIA features about 400 sites (e.g. Haiman 1994; Cohen and Cohen-Amin 2004), $\sim 50$ of which have been excavated (Cohen and Cohen-Amin 2004). The more elaborate sites include enclosed compounds traditionally referred to as "fortresses," pillared houses, water cisterns, and installations that have been interpreted as livestock enclosures, storage pits (silos), and threshing floors. The pottery assemblage of these sites belongs to the early phase of the Iron IIA (Mazar and Panitz-Cohen 2001:274; Herzog and Singer-Avitz 2004). Contemporaneous sites that may have been connected to this system can be found in the Beer-Sheba Valley (mainly the large site of Tel Masos Stratum II and the smaller settlements of Tel Esdar II, Arad XII, and BeerSheba VII) and the Nahal Besor area (Finkelstein 1995:103-26). The copper production site of Khirbet en-Nahas in Jordan, south of the Dead Sea, seems to have reached its peak of activity in the same timeframe (Finkelstein and Piasetzky 2008).

Despite thorough field research, major issues related to the Negev Highlands sites remain in dispute. The first relates to the nature of the sites. Some scholars interpreted them as representing the activity of the Israelite United Monarchy (King Solomon) along the main trade routes in the desert (e.g. Cohen 1979; Cohen and Cohen-Amin 2004; for a revised version of this view, see Haiman 1994, 2003). Accordingly, they understood the main component in many of the sites-the enclosed compound - as a fortress built by the northern authority in order to exert its control over the area. Other

${ }^{1}$ The Martin (Szusz) Department of Land of Israel Studies and Archaeology, Bar-Ilan University, Ramat-Gan 52900, Israel. Also: Radiocarbon Dating and Cosmogenic Isotopes Laboratory, Kimmel Center for Archaeological Science, Weizmann Institute of Science, Rehovot 76100, Israel. Corresponding author. Email: Elisabetta.Boaretto@weizmann.ac.il.

${ }^{2}$ The Jacob M. Alkow Department of Archaeology and Ancient Near Eastern Civilizations, Tel-Aviv University, Tel-Aviv 69978, Israel.

${ }^{3}$ The Martin (Szusz) Department of Land of Israel studies and Archaeology, Bar-Ilan University, Ramat-Gan 52900, Israel. Also: Kimmel Center for Archaeological Science, Weizmann Institute of Science, Rehovot 76100, Israel 
scholars saw the sites as representing a sedentarization process of local pastoral-nomadic groups (Rothenberg 1967; Finkelstein 1995:103-26).

The second issue is the exact date of the Negev Highlands sites. Since the pottery assemblages from the Negev Highlands sites are relatively limited, and since the sites are located in the arid zone, far from the main centers further north where the sequence of the Iron Age assemblage has been established, fixing the precise time of commencement of activity and abandonment of these sites can be challenging (see e.g. Fantalkin and Finkelstein 2006 for the possibility that the wave of settlement in the Negev Highlands commenced in the late Iron I). Turning to absolute chronology, dating the Negev Highlands sites is part of the broader debate over the chronology of the late Iron I and the Iron IIA in the Levant (see updated summaries of the different views in Mazar 2005, representing the "Modified Conventional Chronology"; Finkelstein 2005, representing the Low Chronology).

Establishing an absolute date for the Negev Highlands sites is crucial for reconstructing the history of the arid zones in the Iron Age. If the sites date to the mid-10th century BCE (High Chronology and Modified Conventional Chronology), they may be affiliated with the founders of the Jerusalem dynasty; if they date to the late 10th and 9th century (Low Chronology), they should be interpreted against the background of a different territorio-political landscape. Dating the Negev Highlands sites is also important for understanding the background of the Sheshonq I (biblical Shishak-1 Kings 14:25) campaign in the south in the second half of the 10th century BCE (see more below).

Two Iron Age sites in the Negev Highlands-Kadesh-Barnea and Nahal Elah-supplied a few radiocarbon dates (Carmi and Segal 2007; Bruins and van der Plicht 2007). The determination for Nahal Elah $(2840 \pm 15$ BP) was obtained from wood charcoal and hence, due to the "old wood effect," may provide only a terminus post quem for the construction of the site. Two charcoal samples and 1 ostrich eggshell fragment from Kadesh-Barnea provided dates too high according to all chronology systems - in the middle of the 2nd millennium BCE (Carmi and Segal 2007). Another measurement from Kadesh Barnea was obtained from a short-lived sample; however, the sample (dated $2930 \pm 30 \mathrm{BP}$-Bruins and van der Plicht 2007) probably originated from an earlier, pre-Iron IIA stratum at the site (Singer-Avitz 2008:77). An important, circumstantial piece of information comes from the large-scale Iron Age dating project of recent years, which concentrated mainly on short-lived samples taken from sites further north. The results of this project put the transition from the late Iron I to the Iron IIA in the last $40 \mathrm{yr}$ of the 10th century, i.e. about 940-900 BCE (Boaretto et al. 2005; Sharon et al. 2007), which makes $\sim 940 \mathrm{BCE}$ the earliest possible date for the Iron IIA sites in the Negev Highlands.

The 2 questions raised above - the function and date of the Negev Highlands sites - have recently been re-addressed in the course of a new field and laboratory project, which focused on geoarchaeological investigation (Shahack-Gross and Finkelstein 2008). The strategy of this project is to conduct small-scale, modern-method excavations in which all possible data from a given site are retrieved. The procedures used include careful sieving and picking; flotation where necessary; botanical identification of seeds and wood; zooarchaeological analysis; use of microscopic, spectroscopic, and isotopic techniques; and ${ }^{14} \mathrm{C}$ dating. Two sites have thus far been investigated: Atar Haroa in 2006-2007 and Nahal Boqer in 2008.

Atar Haroa is located $\sim 7 \mathrm{~km}$ northeast of Sede Boqer (G.R. 1359 0352). The site is built on a low hill (elevation $550 \mathrm{~m}$ asl) overlooking a broad valley composed of alluvial sediments (Figure 1). The site was excavated in the 1960s by Cohen (1970). It includes an oval compound with a belt of broadrooms surrounding a large courtyard, a group of pillared houses and other elements that have been interpreted as a threshing floor and field terraces (Figure 2). Cohen excavated several broad-rooms 


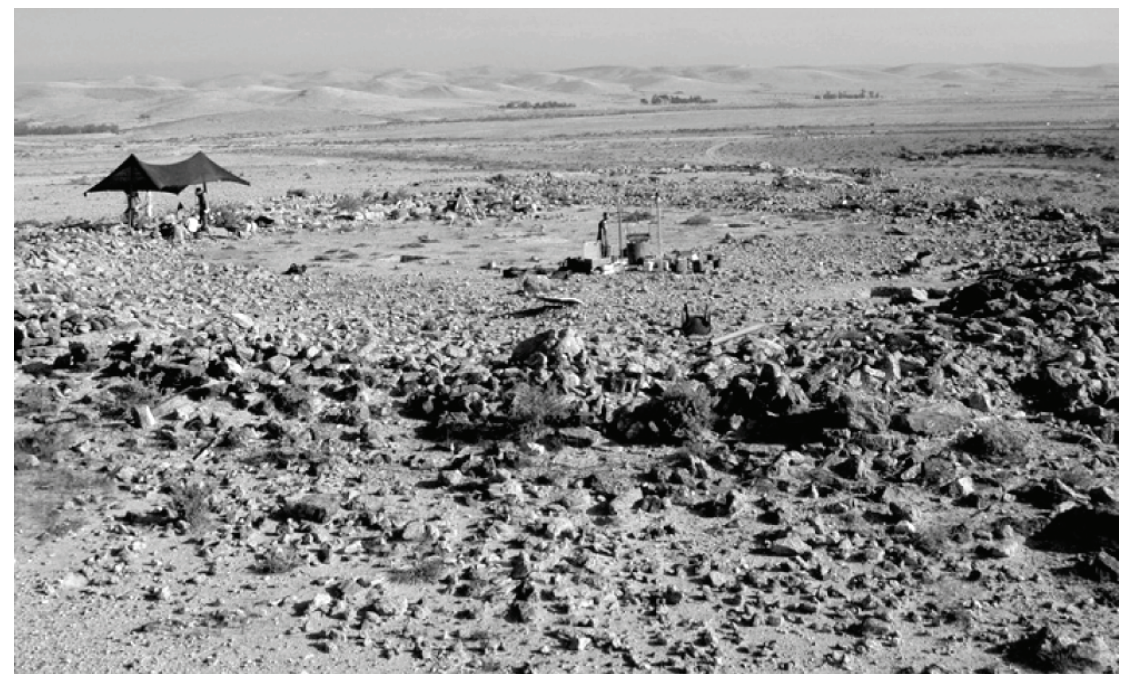

Figure 1 The site of Atar Haroa, looking north

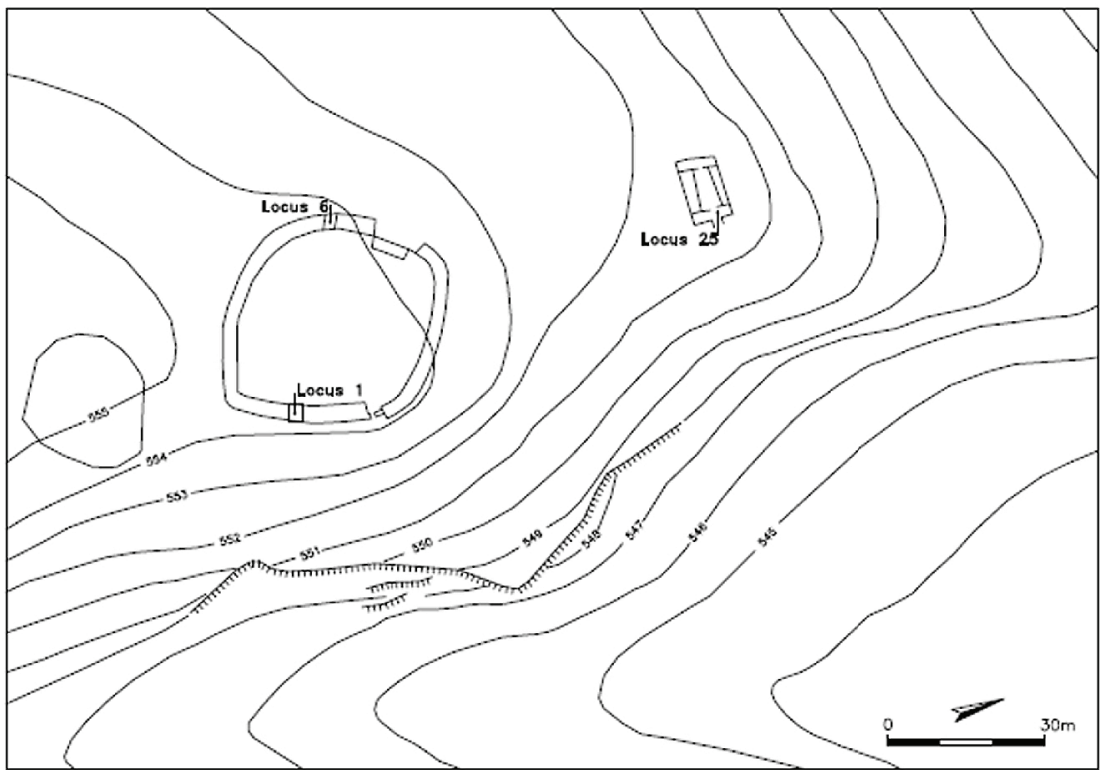

Figure 2 Map of Atar Haroa, indicating loci sampled for this study

in the oval structure (described as "casemates") and 1 pillared house. He identified the oval compound as an Israelite fortress that was built in the days of King Solomon (traditionally 970-931 $\mathrm{BCE}$ ) in order to control the southern trade routes and protect the borders of his kingdom. In each of the excavated rooms, Cohen reported a gray-colored floor with signs of ashes, which he interpreted as evidence of the destruction of the site. He suggested associating this supposed destruction with the military campaign to Canaan undertaken by Pharaoh Sheshonq I in the late 10th century BCE (traditionally 926 BCE—Kitchen 1986:293-4).

The recent excavations at Atar Haroa focused on the rooms and courtyard of the oval structure, the pillared houses, the feature identified by Cohen as a "threshing floor," and wadi terraces below the 
site. The geoarchaeological study showed that the inhabitants subsisted on pure pastoralism; no evidence of agricultural activity was retrieved. In addition, no evidence of human-inflicted destruction could be detected (Shahack-Gross and Finkelstein 2008). These results shed light on the first issue discussed above, namely, the nature of an Iron Age site in the Negev Highlands and the subsistence practices of its inhabitants. In this article, we address the second issue - the exact date of the Negev Highlands sites. In what follows, we report the results of a large set of ${ }^{14} \mathrm{C}$ measurements from Atar Haroa.

\section{MATERIALS AND METHODS}

\section{Samples and Provenance}

Fifteen samples of charred seeds and 1 sample of partly charred sheep/goat dung pellet have been ${ }^{14} \mathrm{C}$ dated. The samples were collected by means of field-picking, flotation, and dry-sieving, from 3 localities: Loci 1, 6, and 25 (Figure 2). All 3 loci produced early Iron IIA pottery exclusively.

Locus 1 was excavated in 2006. It constitutes half of a room ("casemate") in the eastern side of the oval compound. Three date pits, 2 barley seeds, and 1 sheep/goat dung pellet were dated from this locus. All were obtained by flotation from an ashy gray feature in the form of a hearth on the room's floor. All samples were buried under a $\sim 1$-m-thick mixture of yellow wind-blown (loess) sediment and collapsed construction stones (Figure 3). Pottery was mostly found on the floor, while some sherds and a few grinding stones were recovered from the collapse debris, about $30-50 \mathrm{~cm}$ above the floor level. The latter probably represent items stored on the roof of this room.

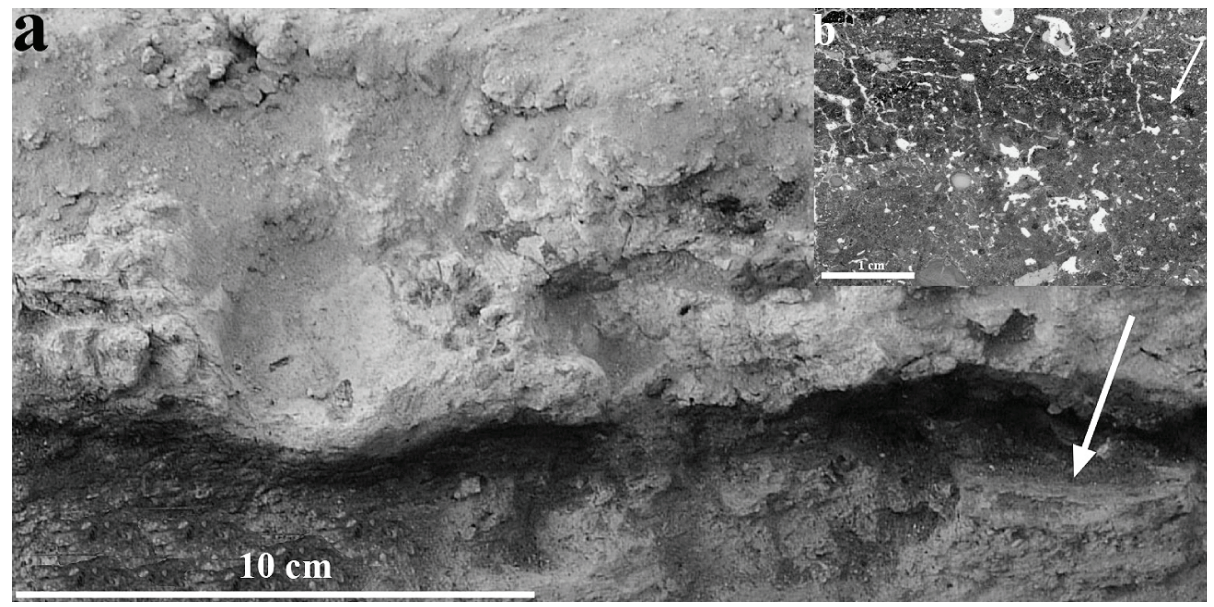

Figure 3 Locus 1. (a) Macroscopic section of hearth on floor. The arrow indicates the level of the floor where the sediment is reddened. The hearth sediment above the floor is composed of black, soft sediment at the bottom and white sediment above it. The seeds for dating were collected from these sediments. (b) Scan of micromorphological thin section produced from the lower part of the hearth. The arrow indicates the floor level. The black sediment above the floor is composed of macroscopic and microscopic charred vegetal material.

Locus 6 was also excavated in 2006. It constitutes half of a room in the western part of the oval compound. Several date pits were found here during the excavation, located near the eastern wall of the room. The pits were associated with gray sediment found on the floor of this room, but no hearth structure could be identified. Five of these date pits have been dated. While in Locus 1 only one floor surface was identified, in Locus 6 the sediments above the floor are bedded, including several 
thin (1-2 cm thick) horizontal layers with a total thickness of $\sim 8-10 \mathrm{~cm}$ (Figure 4). Similar to Locus 1 , these sediments were buried under a mixture of loess sediment and collapsed building stones.

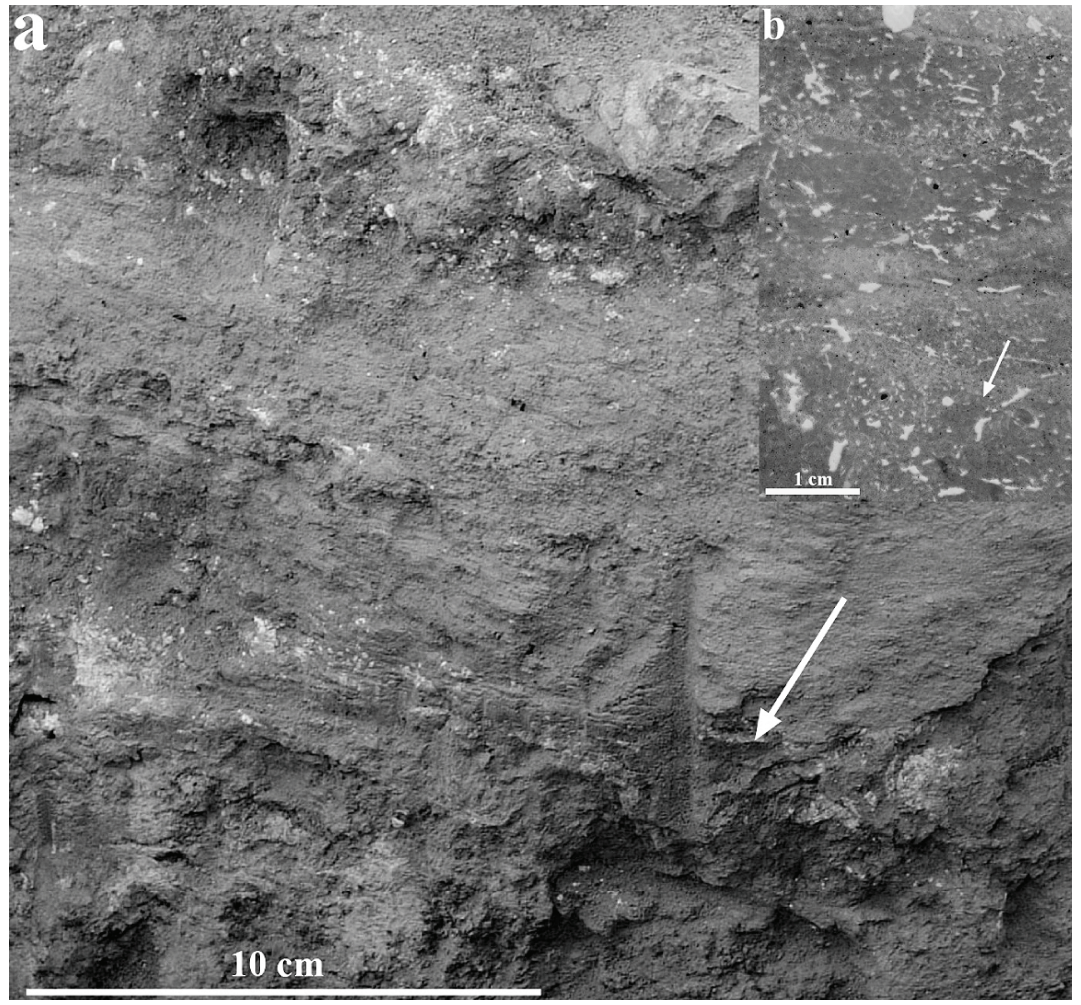

Figure 4 Locus 6. (a) Macroscopic view of the sediments above and below the floor of this excavated room. The floor level is indicated by the arrow. The material below this level is compact reddish-brown sediment. The white nodules at its uppermost part are composed of gypsum. The sediments above the floor level are laminated, including alternations between gray, brown, and yellow sediments. (b) Scan of micromorphological thin section produced from the uppermost part of the laminated accumulation. The arrow indicates the floor level. Microscopic charred material was identified in the gray sediments.

Locus 25 was opened in 2007. It is located in the northern part of the entrance (eastern) room of a well-preserved pillared house previously excavated by Cohen (Locus 15 in Cohen 1970). The house is located $\sim 50 \mathrm{~m}$ to the north of the oval compound. Cohen had cleared this room down to the surface of its floor. In 2007, the floor was re-exposed and a sectional trench, $0.8 \mathrm{~m}$ wide, was carefully dug into and below the floor. A round hearth sunk $\sim 0.30 \mathrm{~m}$ below the floor level was identified (Figure 5). The hearth sediments were dark gray and included wood charcoal, charred seeds, and dung pellets. Five seeds from this locus have been dated: 2 date pits, 2 barley seeds, and 1 grape seed.

\section{Radiocarbon Procedure}

The material selected for ${ }^{14} \mathrm{C}$ dating was pretreated using the procedure described in Yizhaq et al. (2005) and Rebollo et al. (2008), which aims at removing all carbon-bearing contaminants. A general acid-base-acid protocol was followed in order to remove contaminants (Olson and Broecker 1958). The samples indicated different state of preservation based on the mass loss during the pretreatment. After pretreatment and before dating, the samples were analyzed using Fourier transform 


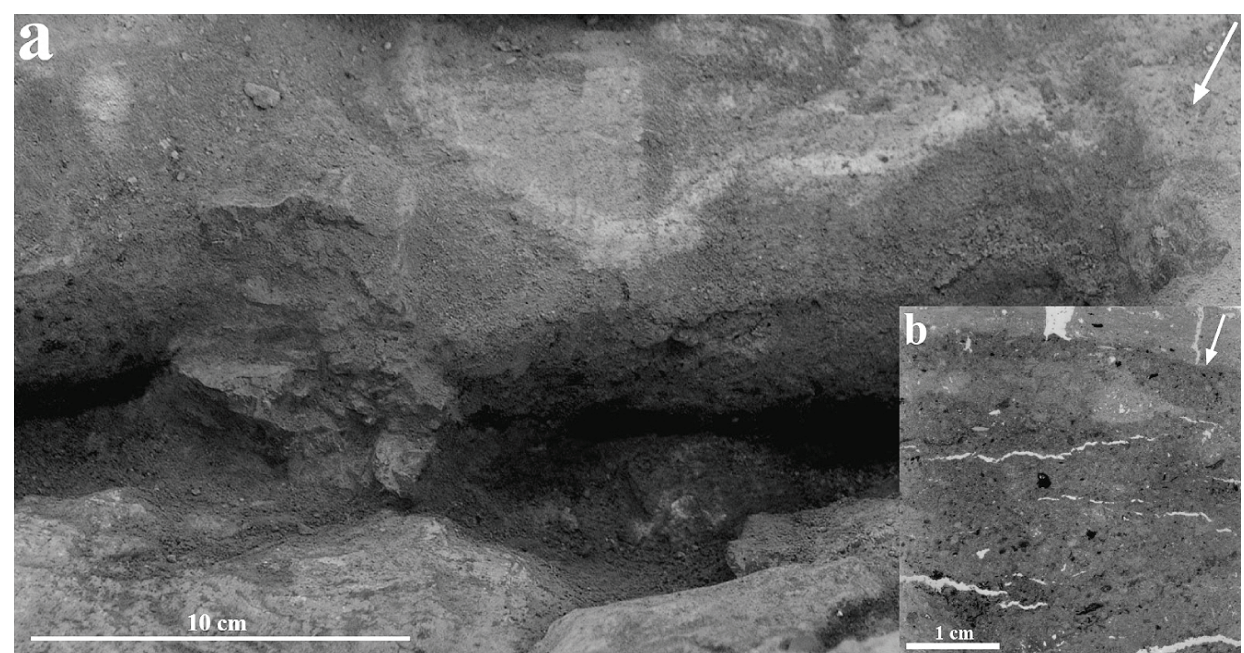

Figure 5 Locus 25. (a) Macroscopic section of hearth, sunken below the floor level (the latter indicated by the arrow). Note the chert rocks that delineate this feature. (b) Scan of micromorphological thin section produced from the top part of the hearth. The arrow indicates the floor level. The material below it included microscopic charred material.

infrared (FTIR) spectroscopy in order to determine the purity of the charcoal recovered. After pretreatment, the samples were oxidized in vacuum with $\mathrm{CuO}$ at $900{ }^{\circ} \mathrm{C}$ and prepared as graphite for the ${ }^{14} \mathrm{C}$ determination using accelerator mass spectrometry (AMS). All samples provided enough carbon for the AMS measurement.

${ }^{14} \mathrm{C}$ ages are reported in conventional ${ }^{14} \mathrm{C}$ years before present (BP) in accordance with international convention (Stuiver and Polach 1977). Thus, all calculated ${ }^{14} \mathrm{C}$ ages have been corrected for isotopic fractionation based on the stable carbon isotope ratio $\left(\delta^{13} \mathrm{C}\right.$ value). Calibrated ages in calendar years have been obtained from the calibration tables of Reimer et al. (2004) using OxCal v 3.10 (Bronk Ramsey 1995, 2001).

\section{RESULTS}

All samples measured in this study have been analyzed using the same laboratory procedure. The pretreatment efficiency (sample mass left after treatment compared to the initial mass) was as low as $6.2 \%$ (RTT 5491) and as high as $75.6 \%$ (RTT 5356). Such variation in charcoal recovery indicates different states of preservation of the material in the site, with Locus 1 being in general the least well preserved.

Despite the loss of material during the pretreatment procedure, all samples yielded a high carbon percent, between 42.3 to $72.4 \%$, as expected for charred material. The only exception is sample RTT 5488 - a dung pellet that yielded only $2.6 \%$ carbon. Such low carbon content is due to the presence of quartz in the final material as detected by the FTIR analysis of the final pretreatment product. Quartz grains are not eliminated during the pretreatment. Nevertheless, there is no correlation between the samples' state of charcoal preservation and their age (Figure 6).

The ${ }^{14} \mathrm{C}$ calibrated ages are presented in Table 1 . The dates are grouped by loci and ordered by age for each locus, from youngest to oldest. The calibrated age probability distributions are given in Figure 7, following the same order as in Table 1 . The calibrated ranges are very similar and considering 


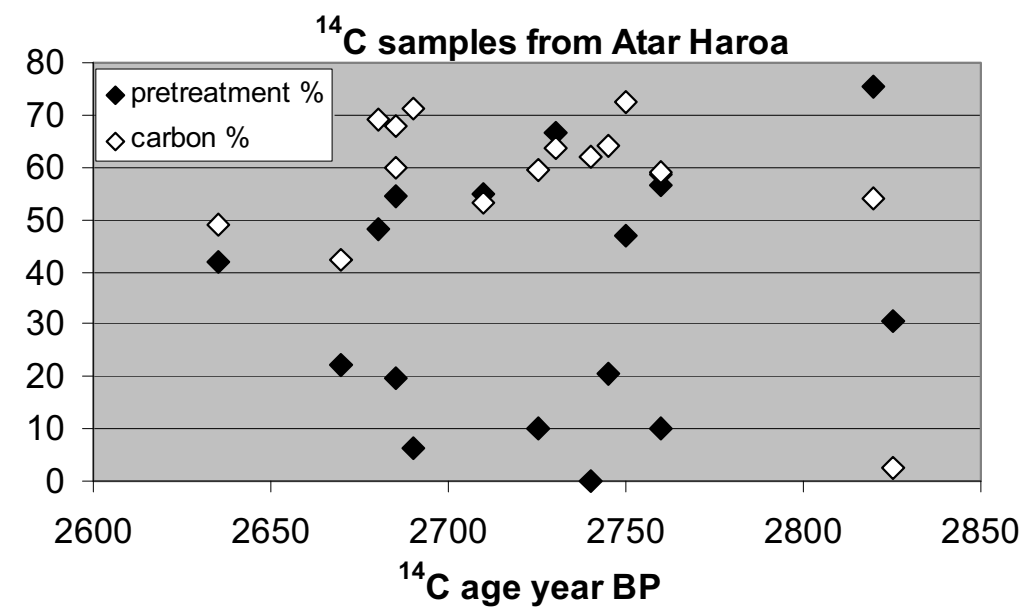

Figure 6 Plot showing the relationship between the percent of material left after pretreatment and percent of carbon in the same material relative to the ${ }^{14} \mathrm{C}$ age of the samples. There is no correlation between sample state of preservation and its age.

Table $1{ }^{14} \mathrm{C}$ results obtained for the samples from Atar Haroa, with sample number, botanical identification, ${ }^{14} \mathrm{C}$ age in yr BP, calibrated ranges for $\pm 1 \sigma$ and $\pm 2 \sigma$, collection site, preparation $\%$ and carbon $\%$ after pretreatment and stable isotope ratios. The dates are ordered by locus number and in each locus from the youngest to the oldest.

\begin{tabular}{|c|c|c|c|c|c|c|c|c|}
\hline $\begin{array}{l}\text { Lab \# } \\
\text { (RTT-) }\end{array}$ & Type & $\begin{array}{l}{ }^{14} \mathrm{C} \text { age } \\
\pm 1 \sigma \\
\text { yr BP }\end{array}$ & $\begin{array}{l}\text { Calibrated range } \\
\pm 1 \sigma\end{array}$ & $\begin{array}{l}\text { Calibrated range } \\
\pm 2 \sigma\end{array}$ & $\begin{array}{l}\text { Collection } \\
\text { site }\end{array}$ & prep $\%$ & $\mathrm{C} \%$ & $\begin{array}{l}\delta^{13} \mathrm{C} \\
\% 0 \\
\text { PDB }\end{array}$ \\
\hline 5357 & date & $2670 \pm 40$ & $\begin{array}{l}895(9.2 \%) 875 \mathrm{BC} \\
845(59.0 \%) 795 \mathrm{BC}\end{array}$ & $910(95.4 \%) 790 \mathrm{BC}$ & L. 1, Sq. C3 & 22.0 & 42.3 & -25.7 \\
\hline 5490 & barley & $2685 \pm 40$ & $\begin{array}{l}895(18.1 \%) 870 \mathrm{BC} \\
850(50.1 \%) 800 \mathrm{BC}\end{array}$ & $920(95.4 \%) 790 \mathrm{BC}$ & L. 1 & 19.7 & 60.0 & -23.9 \\
\hline 5491 & barley & $2690 \pm 40$ & $\begin{array}{l}895(21.5 \%) 865 \mathrm{BC} \\
860(46.7 \%) 805 \mathrm{BC}\end{array}$ & $920(95.4 \%) 790 \mathrm{BC}$ & L. 1 & 6.2 & 71.0 & -22.2 \\
\hline 5716 & date & $2740 \pm 40$ & $920(68.2 \%) 830 \mathrm{BC}$ & $980(95.4 \%) 800 \mathrm{BC}$ & L. 1 , & 29.1 & 61.8 & -23.1 \\
\hline 5717 & date & $2750 \pm 40$ & $925(68.2 \%) 830 \mathrm{BC}$ & $1000(95.4 \%) 810 \mathrm{BC}$ & L. 1 , Sq. C2 & 46.8 & 72.4 & -23.5 \\
\hline 5488 & $\begin{array}{l}\text { dung } \\
\text { pellet }\end{array}$ & $2825 \pm 40$ & $1030(68.2 \%) 910 \mathrm{BC}$ & $1120(95.4 \%) 890 \mathrm{BC}$ & $\begin{array}{l}\text { L. 1, Sq. C3, } \\
\text { B-100 }\end{array}$ & 30.6 & 2.6 & -22.9 \\
\hline 5719.2 & date & $2680 \pm 40$ & $\begin{array}{l}\text { o) } 870 \mathrm{BC} \\
\text { o) } 800 \mathrm{BC}\end{array}$ & $910(95.4 \%) 790 \mathrm{BC}$ & L. 6, Sq. Y39 & 48.0 & 69.0 & -24.5 \\
\hline 5720 & date & $2685 \pm 40$ & $\begin{array}{l}895(18.1 \%) 870 \mathrm{BC} \\
850(50.1 \%) 800 \mathrm{BC}\end{array}$ & $920(95.4 \%) 7$ & L. 6, Sq. Y39 & 54.6 & 68.0 & -23.8 \\
\hline 5683 & date & $2760 \pm 40$ & $\begin{array}{l}970(4.9 \%) 960 \mathrm{BC} \\
940(63.3 \%) 840 \mathrm{BC}\end{array}$ & o) $820 \mathrm{BC}$ & Sq. Y39 & 10.0 & 58.6 & -23.3 \\
\hline 5718 & date & $2760 \pm 40$ & $\begin{array}{l}970(4.9 \%) 960 \mathrm{BC} \\
940(63.3 \%) 840 \mathrm{BC}\end{array}$ & $1010(95.4 \%) 820 \mathrm{BC}$ & L. 6, Sq. Y39 & 56.4 & 59.0 & -24.2 \\
\hline 5356 & date & $2820 \pm 35$ & $1015(68.2 \%) 920 \mathrm{BC}$ & $1120(95.4 \%) 890 \mathrm{BC}$ & L. 6 & 75.6 & 54.0 & -23.4 \\
\hline 5723 & grape & $2635 \pm 40$ & $830(68.2 \%) 785 \mathrm{BC}$ & $900(95.4 \%) 760 \mathrm{BC}$ & L. 25 & 42.0 & 49.0 & -24.3 \\
\hline 5721 & barley & $2710 \pm 40$ & $900(68.2 \%) 820 \mathrm{BC}$ & $930(95.4 \%) 800 \mathrm{BC}$ & L. 25 & 55.6 & 53.4 & -23.8 \\
\hline 5700 & date & $2725 \pm 40$ & $905(68.2 \%) 825 \mathrm{BC}$ & $\begin{array}{l}980(2.7 \%) 950 \mathrm{BC} \\
940(92.7 \%) 800 \mathrm{BC}\end{array}$ & L. 25 & 10.0 & 59.3 & -23.4 \\
\hline 5699 & & $2730 \pm 40$ & & $980(95.4 \%) 800 \mathrm{BC}$ & L. 25 & 66.5 & 63.7 & -24.3 \\
\hline 5722 & barley & $2745 \pm 40$ & $920(68.2 \%) 830 \mathrm{BC}$ & $1000(95.4 \%) 810 \mathrm{BC}$ & L. 25 & 20.6 & 64.0 & -25.2 \\
\hline
\end{tabular}


the range based on $\pm 1 \sigma$, they cover mostly the 9th century BCE with the exception of 2 samples, RTT 5488 dung pellet from Locus 1 and RTT 5356 date seed from Locus 6, which cover the end of the 11 th and the entire 10th centuries BCE.

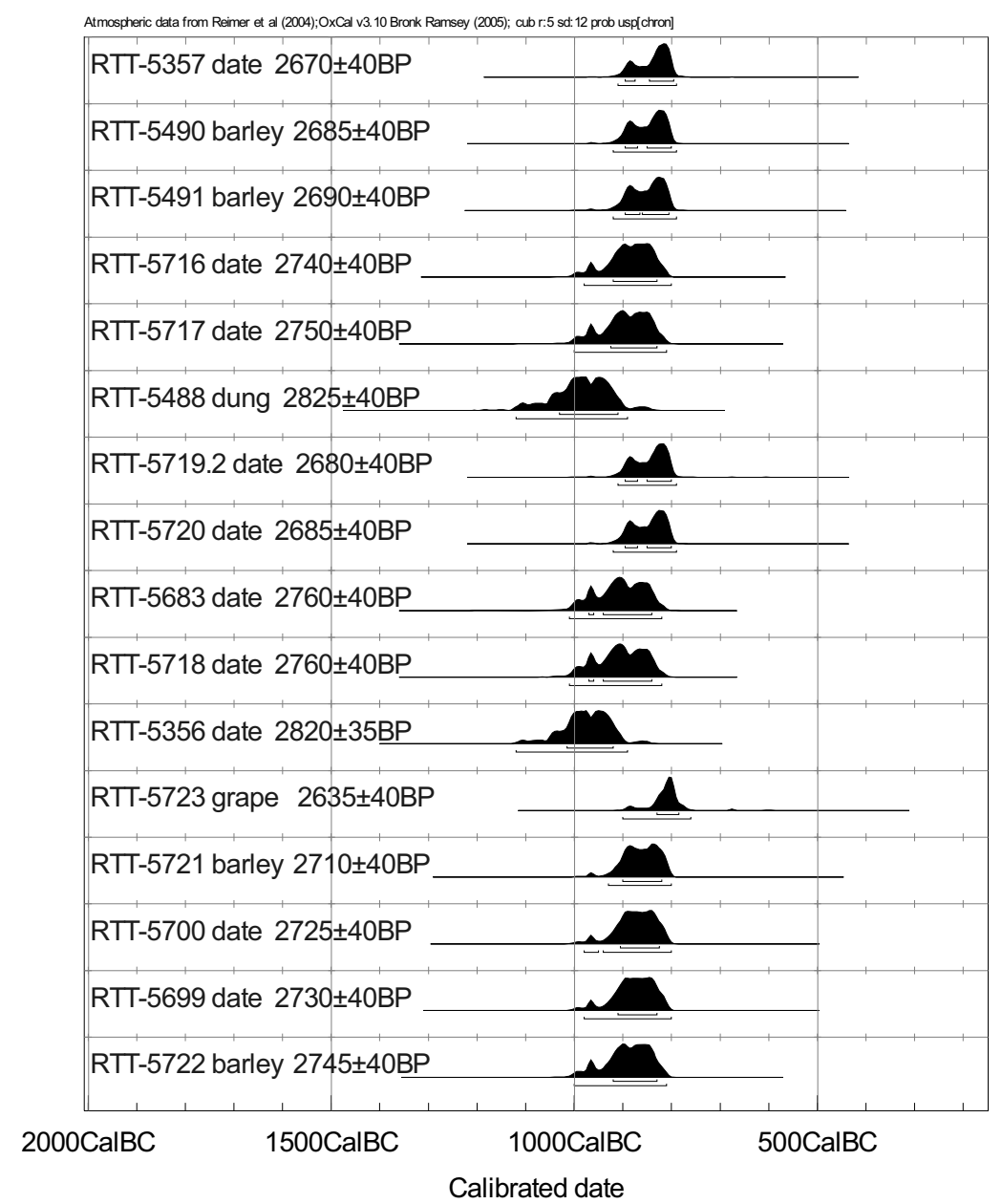

Figure 7 Probability distribution of the calibrated ages of the samples from Atar Haroa. The samples are ordered according to locus number and for the same locus from youngest to oldest.

Sample RTT 5488 is a dung pellet whose ${ }^{14} \mathrm{C}$ and carbon content may represent a mixed source of carbon, possibly derived from plants that integrate atmospheric ${ }^{14} \mathrm{C}$ for several decades. Therefore, it can only be considered as providing a terminus post quem for the construction of the site and is excluded from further discussion. Sample RTT 5356 is a date pit, recovered from an ash accumulation with 4 other date pits. The age range of these date pits is $140 \mathrm{yr}$, which is $\sim 3$ standard deviations. Therefore, these date pits may represent long-term activities and use of the given space. This interpretation is supported by the microstratigraphy of Locus 6, indicating continuous occupation represented by a series of laminated surfaces (Figure 5). 


\section{DISCUSSION}

The exclusion of sample RTT 5488 (as the source of carbon in this material is not clear) makes sample RTT 5356 the oldest retrieved at Atar Haroa. It may represent an early phase of activity at the site, in the 10th century BCE. Based on a single reading, it is difficult to be more precise; still, since most other results for \pm 1 - and $\pm 2-\sigma$ cover the late 10th and 9th centuries BCE, and as this is the only result that falls exclusively in the 10th century (and in part in the late 11th century BCE), dating the construction of the site to the second half of the 10th century seems reasonable. This single date is too inconclusive to shed light on the much-discussed date of transition from the Iron I to the Iron IIA (recently Finkelstein and Piasetzky 2006; Sharon et al. 2007; Mazar and Bronk Ramsey 2008).

The other 14 dates represent the main phase of activity at this early Iron IIA site. The $\pm 1 \sigma$ dates for many of them fall exclusively in the 9th century BCE. Three strata in the Shephelah (Tell es-Safi IV, Tel Zayit and Lachish IV), which feature the next ceramic phase in the south (the late Iron IIA), provided 17 short-lived ${ }^{14} \mathrm{C}$ determinations (Sharon et al. 2007:39-40; Tappy et al. 2006; Carmi and Ussishkin 2004, respectively). These dates range from $2780 \pm 44$ to $2616 \pm 40 \mathrm{BP}$, with 15 of them spanning between $2750 \pm 20$ and $2640 \pm 40 \mathrm{BP}$. This range is very similar to the one obtained for Atar Haroa, and they too cover mostly the 9th century BCE. These results enable placing the early Iron IIA from some time in the second half of the 10th century and in the first half of the 9th century and the late Iron IIA thereafter, probably in the second half of that century.

These data seem to negate the dating of the transition from early to late Iron IIA in the south at $\sim 900$ BCE (Herzog and Singer-Avitz 2004:229). Placing this transition in the first half of the 9th century BCE (Fantalkin and Finkelstein 2006:22) seems to fit the Atar Haroa results better. Note that ${ }^{14} \mathrm{C}$ determinations and historical considerations put the destruction of late Iron IIA Tell es-Safi IV in the second half of the 9th century BCE, after the accession of Hazael to the throne in Damascus in 843/2 BCE (Sharon et al. 2007:39; Maeir 2004, respectively).

The large set of ${ }^{14} \mathrm{C}$ determinations from Atar Haroa demonstrates the importance of using only short-lived samples to resolve high-precision chronological questions such as the date of the Iron IIA sites in the Negev Highlands. Other scholars used charcoal samples (Bruins and van der Plicht 2007), introducing a further uncertainty in the chronological interpretation due to the old-wood effect.

Several years ago, one of us suggested (Finkelstein 1995:110) that the more complex early Iron IIA sites in the Negev Highlands, such as Atar Haroa, developed in stages: first the oval compound was constructed and in a subsequent stage pillared houses were dispersed around it, creating a sort of a village. A comparison of the results from the oval compound (Loci 1 and 6) and from the 4-room building (Locus 25) does not supply clear evidence to support or reject this idea. The results from the 4-room house are similar to those from Locus 1 and some of the readings from Locus 6 of the oval compound, but they lack the early phase of activity, as indicated by the early result from Locus 6.

Atar Haroa and the other Negev Highlands sites constitute part of a broader early Iron IIA settlement phenomenon, which also includes: a) a system of settlements in the Beer Sheba Valley, which is best represented by the large and prosperous site of Tel Masos Stratum II, and by smaller sites, such as Beer Sheba VII and Arad XII; b) sites in the Besor region (for the latter see Gophna and SingerAvitz 1984; Gazit and Gophna 1993). The ${ }^{14} \mathrm{C}$ dates from Atar Haroa, especially the main group, which covers the 9th century BCE, help to set this settlement phenomenon in historical context. 
The Atar Haroa data may shed light on the Sheshonq I campaign in Canaan, which took place in the second half of the 10th century BCE. ${ }^{4}$ A large group of toponyms in the relief describing the campaign, engraved on a wall of the temple of Amun at Karnak, refer to places in the Negev (B Mazar 1957; Kitchen 1986:293-300, 432-47; Na'aman 1998). Scholars identified at least some of these toponyms with the Iron IIA sites in the Negev Highlands and associated ostensible destruction layers at these sites-including Atar Haroa-with the campaign (e.g. Cohen 1970, 1979). Fixing the beginning of activity at Atar Haroa in the late 10th century adheres to the possibility that some of the Sheshonq I toponyms relate to the Negev Highlands sites (but note that most of these toponyms should be sought in the Beer Sheba Valley and the Besor region). Yet, the results of the new project reject the theory that Atar Haroa in particular and other sites in the region in general were destroyed in the course of this campaign. First, the new excavation at Atar Haroa found no evidence for destruction and the ashy material in the rooms of the oval compound and the 4-room house probably result from hearth-ash spread on their floors. Second, the ${ }^{14} \mathrm{C}$ data indicate that Atar Haroa was active in the 9th century BCE, long after the Sheshonq I campaign. This evidence may support the proposal that the Sheshonq I campaign in fact boosted the activity in the south, including the Negev Highlands - activity that may have started a short time before the campaign (Fantalkin and Finkelstein 2006).

The commencement of the wave of settlement in the Beer Sheba Valley, Besor region, and the Negev Highlands may have been connected to the increase in copper production at Khirbet enNahas in the eastern Arabah, "the largest Iron Age copper-smelting site in the southern Levant" (Levy et al. 2004:867; Hauptmann 2007:127). Controlling trade of the Khirbet en-Nahas copper could have been one of the targets of the Sheshonq I campaign. With the cessation of contacts with Cyprus, the Khirbet en-Nahas copper must have been the major - if not only — source of copper for Egypt. The large set of ${ }^{14} \mathrm{C}$ readings from Khirbet en-Nahas (Levy et al. 2004, 2005) seems to indicate that the site reached its peak prosperity in the first half of the 9th century BCE (Finkelstein and Piasetzky 2008), that is, in the early Iron IIA, parallel to the wave of settlement in the Beer Sheba Valley, Besor region, and Negev Highlands. Indeed, Tel Masos II supplied evidence for copper activity (Kempinski et al. 1983:21) and yielded an exceptionally large number of copper/bronze items (Crüsemann 1983; Lupu 1983:202-3).

The abandonment of the Negev Highlands sites may have been connected to the gradual decline of this copper-oriented economic prosperity due to the renewal of import of Cypriot copper to the Levant in the late Iron IIA (for the latter see Knauf 1995:112-3; Hauptmann 2007:153). Copper production at Khirbet en-Nahas ceased in the late 9th century BCE (Finkelstein and Piasetzky 2008).

\section{CONCLUSION}

The set of ${ }^{14} \mathrm{C}$ determinations from Atar Haroa in the Negev Highlands places the site in the 9th century BCE, or indicates that it was established in the 10th century BCE, possibly in the second half, and that it continued to be active at least in the first half of the 9th century BCE. Hence, the Atar Haroa measurements seem to show that the early Iron IIA phase in the ceramic typology of southern Israel lasted until the mid-9th century BCE—-somewhat later than previously suggested.

\footnotetext{
${ }^{4}$ Because of difficulties in the Egyptian chronology in the Third Intermediate Period, the traditional dating of the reign of Sheshonq I in general and the campaign (to $926 \mathrm{BCE}$ ) in particular are based on the biblical date, in the fifth year of Rehoboam (1 Kings 14:25; Wente 1976:276). It is safer to say that the campaign took place some time in the second half of the 10th century BCE (Finkelstein 2002).
} 


\section{ACKNOWLEDGMENTS}

We wish to thank Dr E Weiss of Bar-Ilan University for the botanical identifications. This study was enabled through an Israel Science Foundation grant (642/05) to I F and R S-G. Excavations were funded by the Chaim Katzman Archaeology Fund at Tel Aviv University and conducted with the help of Sede-Boqer Field School and students of the Institute of Archaeology of Tel Aviv University.

\section{REFERENCES}

Boaretto E, Jull AJT, Gilboa A, Sharon I. 2005. Dating the Iron Age I/II transition in Israel: first intercomparison results. Radiocarbon 47(1):39-55.

Bronk Ramsey C. 1995. Radiocarbon calibration and analysis of stratigraphy: the OxCal program. Radiocarbon 37(2):425-30.

Bronk Ramsey C. 2001. Development of the radiocarbon calibration program. Radiocarbon 43(2A):355-63.

Bruins HJ, van der Plicht J. 2007. Radiocarbon dating the "Wilderness of Zin." Radiocarbon 49(2):481-97.

Carmi I, Segal D. 2007. Radiocarbon dates. In: Cohen R, Bernick-Greenberg H. Excavations at Kadesh Barnea (Tell el-Qudeirat) 1976-1982. Jerusalem: Israel Antiquities Authority. p 303-6.

Carmi I, Ussishkin D. 2004. ${ }^{14} \mathrm{C}$ dates. In: Ussishkin D. The Renewed Archaeological Excavations at Lachish (1973-1994), Volume V. Tel Aviv: Institute of Archaeology. p 2508-13.

Cohen R. 1970. Atar Haroa. Atiqot 6:6-24. In Hebrew.

Cohen R. 1979. The Iron Age fortresses in the central Negev. Bulletin of the American Schools of Oriental Research 236:63-75.

Cohen R, Cohen-Amin R. 2004. Ancient Settlement of the Negev Highlands. Volume II. The Iron Age and the Persian Periods. Jerusalem: Israel Antiquities Authority. 222 p.

Crüsemann F. 1983. Die Kleinfunde. In: Fritz V, Kempinski A. Ergebnisse der Ausgrabungen auf der Hirbet el-Mšaš (Tel Masos) 1972-1975 I: Textband. Wiesbaden: Harrassowitz. p 91-102.

Fantalkin A, Finkelstein I. 2006. The Sheshonq I campaign and the 8th century BCE earthquake: more on the archaeology and history of the south in the Iron IIIA. Tel Aviv 33:18-42.

Finkelstein I. 1995. Living on the Fringe: The Archaeology and History of the Negev, Sinai and Neighboring Regions in the Bronze and Iron Ages. Monographs in Mediterranean Archaeology 6. Sheffield: Sheffield Academic Press. 197 p.

Finkelstein I. 2002. The campaign of Shoshenq I to Palestine: a guide to the 10th century BCE polity. Zeitschrift des Deutschen Palästina-Vereins 118:109-35.

Finkelstein I. 2005. A low chronology update: archaeology, history and Bible. In: Levy TE, Higham T, editors. The Bible and Radiocarbon Dating: Archaeology, Text and Science. London: Equinox. p 31-42.

Finkelstein I, Piasetzky E. 2006. ${ }^{14} \mathrm{C}$ and the Iron Age chronology debate: Rehov, Khirbet en-Nahas, Dan, and Megiddo. Radiocarbon 48(3):373-86.
Finkelstein I, Piasetzky E. 2008. Radiocarbon and the history of copper production at Khirbet en-Nahas. Tel Aviv 35:82-95.

Gazit D, Gophna R. 1993. An unfortified Late Bronze Age site at Gerar: survey finds. Atiqot 22:15-9. In Hebrew.

Gophna R, Singer-Avitz L. 1984. Iron Age I settlements to the west of Tel Beer-sheba. In: Herzog Z. Beersheba II The Early Iron Age Settlements. Tel Aviv: Institute of Archaeology. p 125-31.

Haiman M. 1994. The Iron Age II sites of the Negev Highlands. Israel Exploration Journal 44:36-61.

Haiman M. 2003. The 10th century B.C. settlement of the Negev Highlands and Iron Age rural Palestine. In: Maeir A, Dar S, Safrai Z, editors. The Rural Landscape of Ancient Israel. Oxford: Archaeopress. p 7190.

Hauptmann A. 2007. The Archaeometallurgy of Copper: Evidence from Faynan, Jordan. Berlin: Springer.

Herzog Z, Singer-Avitz L. 2004. Redefining the centre: the emergence of state in Judah. Tel Aviv 31:209-44.

Kempinski A, Rösel H, Gilboa E, Stahlheber Th. 1983. Area A. In: Fritz V, Kempinski A. Ergebnisse der Ausgrabungen auf der Hirbet el-Mšaš (Tel Masos)19721975 I: Textband. Wiesbaden: Harrassowitz. p 7-34.

Kitchen KA. 1986. The Third Intermediate Period in Egypt (1100-650 B.C.). Warminster: Aris \& Phillips. 608 p.

Knauf EA. 1995. Edom: the social and economic history. In: Edelman Vikander D, editor. You Shall Not Abhor an Edomite for He is Your Brother: Edom and Seir in History and Tradition. Atlanta: Scholars Press. p 93117.

Levy TE, Adams RB, Najjar M, Hauptmann A, Anderson JD, Brandl B, Robinson MA, Higham T. 2004. Reassessing the chronology of biblical Edom: new excavations and ${ }^{14} \mathrm{C}$ dates from Khirbet en-Nahas (Jordan). Antiquity 78(302):865-79.

Levy TE, Najjar M, van der Plicht J, Higham T, Bruins HJ. 2005. Lowland Edom and the high and low chronologies: Edomite state formation, the Bible and recent archaeological research in southern Jordan. In: Levy TE, Higham T, editors. The Bible and Radiocarbon Dating: Archaeology, Text and Science. London: Equinox. p 129-63.

Lupu A. 1983. Analysentabellen. In: Fritz V, Kempinski A. Ergebnisse der Ausgrabungen auf der Hirbet elMšaš (Tel Masos) 1972-1975 I: Textband. Wiesbaden: Harrassowitz. p 202-8. 
Maeir AM. 2004. The historical background and dating of Amos VI 2: an archaeological perspective from Tell es-Safi/Gath. Vetus Testamentum 54:319-34.

Mazar A. 2005. The debate over the chronology of the Iron Age in the southern Levant: its history, the current situation, and a suggested resolution. In: Levy TE, Higham T, editors. The Bible and Radiocarbon Dating: Archaeology, Text and Science. London: Equinox. p 5-30.

Mazar A, Bronk Ramsey C. 2008. ${ }^{14} \mathrm{C}$ dates and the Iron Age chronology of Israel: a response. Radiocarbon 50(2):159-80.

Mazar A, Panitz-Cohen N. 2001. Timnah (Tel Batash) II: The Finds from the First Millennium BCE, Text (Qedem 42). Jerusalem: Institute of Archaeology.

Mazar B. 1957. The campaign of Pharaoh Shishak to Palestine. Vetus Testamentum Supplement 4:57-66.

Na'aman N. 1998. Shishak's campaign to Palestine as reflected by the epigraphic, biblical and archaeological evidence. Zion 63:247-76. In Hebrew.

Olson EA, Broecker WS. 1958. Sample contamination and reliability of radiocarbon dates. Transactions of the New York Academy of Science Series II 20:593604.

Rebollo NR, Cohen-Ofri I, Popovitz-Biro R, Bar-Yosef O, Meignen L, Goldberg P, Weiner S, Boaretto E. 2008. Structural characterization of charcoal exposed to high and low $\mathrm{pH}$ : implications for ${ }^{14} \mathrm{C}$ sample preparation and charcoal preservation. Radiocarbon 50(2): 289-307.

Reimer PJ, Baillie MGL, Bard E, Bayliss A, Beck JW, Bertrand CJH, Blackwell PG, Buck CE, Burr GS, Cutler KB, Damon PE, Edwards RL, Fairbanks RG, Friedrich M, Guilderson TP, Hogg AG, Hughen KA, Kromer B, McCormac G, Manning S, Bronk Ramsey
C, Reimer RW, Remmele S, Southon JR, Stuiver M, Talamo S, Taylor FW, van der Plicht J, Weyhenmeyer CE. 2004. IntCa104 terrestrial radiocarbon age calibration, 0-26 cal kyr BP. Radiocarbon 46(3):1029-58.

Rosen SA. 1987. Demographic trends in the Negev Highlands: preliminary results of the emergency survey. Bulletin of the American Schools of Orient Research 266:45-58.

Rothenberg B. 1967. Negev: Archaeology in the Negev and the Arabah. Ramat Gan: Massada. In Hebrew.

Shahack-Gross R, Finkelstein I. 2008. Subsistence practices in an arid environment: a geoarchaeological investigation in an Iron Age site, the Negev Highlands, Israel. Journal of Archaeological Science 35(4):96582.

Sharon I, Gilboa A, Jull TAJ, Boaretto E. 2007. Report on the first stage of the Iron Age dating project in Israel: supporting a Low Chronology. Radiocarbon 49(1):146.

Singer-Avitz L. 2008. The earliest settlement at Kadesh Barnea. Tel Aviv 35:73-81.

Stuiver M, Polach HA. 1977. Discussion: reporting of ${ }^{14}$ C data. Radiocarbon 19(3):355-63.

Tappy RE, McCarter PK, Lundberg MJ, Zuckerman B. 2006. An abecedary of the mid-tenth century B.C.E. from the Judaean Shephelah. Bulletin of the American Schools of Oriental Research 344:5-46.

Wente EF. 1976. Review of K.A. Kitchen, The Third Intermediate Period in Egypt. Journal of Near Eastern Studies 35:275-8.

Yizhaq M, Mintz G, Khalally H, Weiner S, Boaretto E. 2005. Quality controlled radiocarbon dating of bones and charcoal from the early Pre-Pottery Neolithic B (PPNB) of Motza (Israel). Radiocarbon 47(2):193206. 